\title{
Ku zbliżeniu z rosyjską kulturą
}

\author{
Marek PąKCiŃski \\ (Instytut Badań Literackich PAN, Warszawa)
}

Anna Sobieska, WokÓE ALEKSANDRA BEOKA. Z DZIEJÓW POLSKICH FASCYNACJI KULTURA I LITERATURA ROSYJSKA, WydAWNictwo InstyTUTU BadAŃ Literackich, WarszaWA 20I 5 , ss. 448

Monografia Wokót Aleksandra Btoka. Z dziejów polskich fascynacji kulturq i literaturq rosyjskq (Warszawa 20I5, Wydawnictwo IBL PAN) to książka autorki, której zainteresowania naukowe koncentrują się wokół precyzyjnie wyznaczonych obszarów: komparatystyki, historii literatury polskiej i rosyjskiej przełomu XIX i XX wieku, a także historii idei i antropologii literackiej w połączeniu $\mathrm{z}$ aksjosemiotyką. Bez wątpienia do najwybitniejszych osiągnięć Anny Sobieskiej w tym zakresie należą rozpoznania, interpretacje i analizy zebrane w dwóch książkach: Dzieci Hagar. Literackie wizerunki Romów/Cyganów. Studia imagologiczne (Warszawa 2015) oraz recenzowana tu monografia Wokót Aleksandra Btoka (opublikowana również w Warszawie w 2015 roku). Jej niewątpliwą zaletą jest to, że zasadniczy zarys metodologii autorki stanowi zgromadzenie bardzo dużej ilości materiału faktograficznego (dotyczącego niezwykle frapującego i słabo dotychczas zbadanego obszaru kultury), powiązanie go siecią dobrze uzasadnionych skojarzeń i odniesień, a następnie wysnucie $z$ analizy tak ustrukturowanego materiału ostrożnych i głęboko przemyślanych uogólnień o dużym potencjale nowatorstwa, zmierzających w stronę kwestionowania powszechnie przyjmowanych oraz bezrefleksyjnie powielanych schematów i klisz. Ta właśnie precyzja myślenia, a zarazem pasja kwestionowania funkcjonujących w kulturze stereotypów, połączone $\mathrm{z}$ wyjątkową wrażliwością na poetyckie sensy, a także z nieustannym zachwytem nad pięknem słowa spowodowały, że monografia recepcji Błoka jest - w moim przekonaniu - wydarzeniem intelektualnym, nie tylko burzącym stereotypy czy wykazującym ich miałkość, lecz także inicjującym budowę zupełnie nowych fundamentów wzajemnych odniesień obu naszych kultur (tj. polskiej i rosyjskiej).

Nikogo nie trzeba chyba przekonywać, jak bardzo trudnym zadaniem jest skuteczne i twórcze poruszanie się w obszarze z jednej strony wyznaczonym przez 
niewątpliwą polską rusofobię, a z drugiej - przez nasze wspólnotowe doświadczenia historyczne i sporadyczne przejawy (co prawda nader często stymulowanego przez państwo, a nie „samorodnego”) rosyjskiego antypolonizmu. W tej sytuacji, chcąc zbudować wiarygodny obraz tych relacji, należy sięgnać do złożonego splotu niezmiernie ambiwalentnych emocji, stanowiących w systemie semiotycznym polskiej kultury miejsce bardzo wrażliwe. Stereotypy, schematy i klisze są w tym obszarze niezwykle aktywne, zmierzając zawsze do pozornego zasklepienia rany tego, co niejednoznaczne, budzące lęk i niechęć, a zarazem paradoksalne zaintrygowanie czy skrytą fascynację.

Podobnie jak w swej poprzedniej książce Dzieci Hagar, autorka odchodzi tu od najprostszego schematu chronologicznej narracji historycznoliterackiej, koncentrując swoje rozważania wokół kilku najważniejszych jej zdaniem i trafnie wybranych problemów: polskiej pozaborowej rusofobii, kształtującej obraz Rosji i rosyjskiej kultury w epoce Młodej Polski, ogólnego naszkicowania konturów recepcji twórczości Błoka w Polsce międzywojennej, rosyjskiego dyskursu erotycznego, koncentrującego się (w sensie „wychodzenia od...”, ale i „powracania ku...”) wokół poetyckiego motywu „priekrasnoj damy” z wczesnego okresu twórczości rosyjskiego symbolisty, „uwiedzenia” polskich poetów (a także zwykłych odbiorców kultury) przez rosyjski romans cygański, a wreszcie religijnych, „sekciarskich” fascynacji Błoka chłystami i ich związku z obrazami rewolucji w twórczości rosyjskiego poety.

Za walor książki Anny Sobieskiej uznać należy - w moim przekonaniu - jej emocjonalny ton, sytuujące się w obrębie „kobiecego (naukowego) pisania” świadome odejście od ideału pełnej, chłodnej obiektywności. Nie ulega bowiem wątpliwości, że - tak jak zawsze w przypadku pisarstwa naukowego wysokiego lotu - monografia ta ma zarazem „poruszyć pewną sprawę”, zmierzając do rozbicia i modyfikacji zakrzepłej skorupy błędnych przekonań. Należą do nich oczywiście: przekonanie o „wschodnim” (a zatem równocześnie „barbarzyńskim”) charakterze cywilizacji rosyjskiej, przeświadczenie o wyjątkowym „rozchwianiu” rosyjskiej emocjonalności, a tym samym - całej ukształtowanej w tym kręgu kultury, o rosyjskim maksymalizmie, nieznającym kompromisów między sferą idei a rzeczywistością praktyczną, czy też o negatywnym, wewnętrznie „pustym” charakterze prawosławnej wizji Absolutu, co skutkuje obecnością ukrytego w tej kulturze, w jej systemie znaków, „instynktu śmierci”, dążenia do samozagłady. Szczególnym medium propagowania tych stereotypów była polska modernistyczna publicystyka i literatura o charakterze dyskursywnym.

Pod adresem polskich „rusofobów” (Sobieska wymienia wśród nich m.in. Mariana Zdziechowskiego, Romana Dmowskiego, Bolesława Lutomskiego, Władysława Jabłonowskiego, Adama Grzymałę-Siedleckiego, a z późniejszych autorów najczęściej Adolfa Nowaczyńskiego) skierowany jest wyraźnie polemiczny ton 
rozprawy, a przeciwstawieni są im ci autorzy, którzy w dobie modernizmu kładli podwaliny pod „subwersywną”, aprobatywną wizję Rosji. Pierwszym z wymienionych po tej właśnie stronie barykady pisarzy jest Tadeusz Nalepiński, o którym autorka pisze w znamienny sposób: „ów dyskurs emancypacyjny, jaki zainicjował Nalepiński - choć początkowo skazany na niepowodzenie, wypierany przemocą ze świadomości twórców kultury dominującej - miał siłę mobilizującą do zrywu" (s. 52). Następująca dalej fraza autorki o „potencjale bojowym” tej nowej narracji o kulturze rosyjskiej wyznacza stopień emocjonalnego zaangażowania badaczki w zmagania ze stereotypami.

Zorganizowana wokół opozycji „rusofobia - dążenie do zrozumienia rosyjskiej kultury (wzg. rusofilia)" narracja pierwszej części monografii Wokót Aleksandra Btoka jest w pełni przekonująca, jakkolwiek w niektórych przypadkach można zastanawiać się, czy rzeczywiście wszyscy publicyści piszący o Rosji i jej kulturze na początku XX wieku zostali potraktowani sprawiedliwie. Wydaje się, że np. Marian Zdziechowski jako autor bardzo rzetelnej, jak na owe czasy, monografii Pesymizm, romantyzm a podstawy chrześcijaństwa (I9I4), w której aprobatywnie pisał między innymi o Sołowjowie, nie w pełni zasłużył na określenie „specjalista” od rosyjskości („wpływów rosyjskich"), pisane w cudzysłowie, sygnalizującym bez wątpienia ostry sarkazm; tym bardziej że dwie strony dalej Anna Sobieska stwierdza: „Trwająca wciąż gorączka związana $[. .$.$] z rewolucją I9I7 roku, wojna polsko-bolszewicka I920 roku, a w końcu$ także i układ w Rapallo [...] nie były przypadkowym tłem dla - uodpornionej na zmiany - tradycji polskiej nieufności” (s. 55). Nie chodzi w tym przypadku wyłącznie o jakąś zaniechaną tu (także przecież mieszczącą się w obrębie związanych ze stereotypami „rytuałów”) konieczność każdorazowego usprawiedliwiania polskiej rusofobii, lecz o to, że - pod pokładami uproszczeń i uogólnień - trwała przecież i trwa pewna istotna, niedająca się zredukować różnica kulturowa, wyrażająca się nie tylko w „łacińskości” polskiej kultury i „bizantyńskości” kultury rosyjskiej, lecz sygnalizująca pewien istotny moment odmiennego podejścia do świata, odmiennej mentalności. Nie ulega wątpliwości, że różnicę tę eksploatowali niezwykle aktywnie polscy publicyści i twórcy, czyniąc to często na określone polityczne zamówienie. Nie da się jednak zakwestionować faktu, że różnica ta po prostu jest; należałoby ją zatem zreinterpretować, oczyścić z nalotu ksenofobii i nietolerancji (do czego książka Anny Sobieskiej stanowi solidny i bardzo cenny wstęp), nie negując jednak jej obiektywności - bo wydaje się to trudem syzyfowym - a potem, w sposób wolny i nieskrępowany... cieszyć się jej istnieniem.

Podobnie, nieco krzywdzące wobec Tadeusza Nalepińskiego (któremu przyznane zostało skądinąd zaszczytne miano inicjatora dyskursu emancypacyjnego wobec rusofobii) jest jednoznaczne określenie jego próby wglądu w „duszę rosyjską" - dzięki rzadkiej wówczas wśród Polaków wiedzy o rosyjskim symbolizmie - 
mianem „nieudanej”. Jak pisze autorka: „Zestaw idei i wartości, które stanowiły swego rodzaju punkt odniesienia oraz narzędzie analizy i interpretacji, wydaje się u tego krytyka dość zunifikowany. Naczelnym motywem jego dyskursu pozostawało śledztwo w sprawie duszy rosyjskiej, ocena, do jakiego stopnia sugestywnie, prawdziwie przejawia się ona w danym dziele. [...] Nalepiński posłużył się na jej określenie rosyjskim słowem toska, zakładając, że żadne jego tłumaczenie nie odda wszystkich ukrytych w nim odcieni znaczeniowych" (s. 47). W stwierdzeniach tych kryje się zarzut jednostronności podjętej przez Nalepińskiego interpretacji. Bez wątpienia ocena ta - formułowana $\mathrm{z}$ dzisiejszego punktu widzenia (a zwłaszcza w perspektywie wiedzy o subtelności i wielotorowości oddziaływania rosyjskiego symbolizmu na kulturę polską w dwudziestoleciu międzywojennym) jest uzasadniona. Warto jednak pamiętać, że Nalepiński nie posiadał zapewne odpowiednich narzędzi krytycznych do wypracowania innego, bardziej stonowanego czy różnorodnego obrazu. Krytycy młodopolscy posługiwali się - jak przekonująco dowodził Michał Głowiński - figurą „empatycznego wglądu” i parafrazą jako podstawowymi sposobami wejścia w twórczą interakcję z interpretowanym dziełem, natomiast próbując ustalić coś „pewnego” i racjonalnie uzasadnionego na temat przedmiotu swych rozważań, odwoływali się najczęściej (i właściwie - do pewnego momentu - w sposób bezalternatywny) do metodologii pozytywistycznej. Poszukiwanie „istoty rosyjskiej duszy”, a następnie nadanie znalezisku wieloznacznej nazwy, kojarzącej ją z pewnym nastrojem (a zarazem zjawiskiem kulturowym) może być odwołaniem się do zwykłej Taine'owskiej metody określenia zasadniczej ,jakości dominującej” jako niezbędnego etapu krytycznej procedury, nie zaś manifestacją zależności Nalepińskiego od „rusofobicznych” schematów ${ }^{\mathrm{I}}$.

Jak napisała skromnie autorka w zakończeniu swojej książki: „Charakteryzującą niniejsze studium fragmentaryczność potraktować [...] można jako strategię, swoisty materiał do ćwiczeń praktycznych - osiągania chłystowskiego transu albo raczej hezychastycznego, kontemplacyjnego przechodzenia od szczególu do całości, pozwalającego zobaczyć świat w oku wróbla, jak by powiedział, zaprzyjaźniony z rosyjskim symbolizmem i kulturą rosyjską, Leśmian”(s. 388). Jest to - jak sądzę - nie tyle deklaracja zabezpieczająca przed zarzutami niewystarczalności zgromadzonego w studium materiału czy też niekompletności wysnutych tez, lecz ukazanie rzeczywistej logiki rządzącej dyskursem badaczki. Przyjętym w monografii założeniem jest bowiem przeświadczenie, że symbolizm jest nurtem paradygmatycznym dla rosyjskiej mentalności nowoczesnej, a Aleksander Błok jawi się jako wzorcowy, najdoskonalszy symbolista rosyjski, a zatem - w jakimś sensie - wciela pewien „wzorzec duszy rosyjskiej” w całej jej niejednoznaczności i złożoności (autorka 
stwierdza w pewnym miejscu tekstu, iż jest on poetą rosyjskim „największym po Puszkinie" - s. 155). Jakkolwiek bowiem wpływ autora Dwunastu na polską poezję i całą kulturę doby dwudziestolecia został tu przedstawiony w sposób bogaty i przekonujący - istnieją również inne pasjonujące zagadnienia i problemy, które książka ta porusza, analizuje, wyjaśnia. Tworzą one swoistą atmosferę fenomenu entuzjastycznej nierzadko recepcji Błoka, jej niezwykle bogatą ramę. Głównym przedmiotem analizy są tu - jak stwierdza Sobieska - polskie i rosyjskie „struktury mentalne «napikowane» [określenie Jacquesa Lacana - M. P.] tradycjami religijnymi” (s. 227). Jeśli uznać, że struktury te obejmują „Z zewnątrz” całą wykreowaną w danej kulturze rzeczywistość, cały jej porządkujący logos, oznacza to, że nie ma właściwie takiego obszaru relacji polsko-rosyjskich, który potencjalnie nie mógłby się znaleźć w tak zarysowanej perspektywie oglądu. Osobiście wyróżniłbym następujące zagadnienia, które zostały poruszone (a raczej - przywołane w intrygujący, nowatorski sposób) w monografii Anny Sobieskiej o Błoku: r. różnorodne reakcje kultury polskiej i rosyjskiej na nowoczesność, niejako strategie jej oswajania; 2.pojmowanie wolności czy też kreowanie jej obrazu w obu tych kulturach; 3. rewolucja jako nieuchronny punkt zetknięcia się historycznej linii kultury rosyjskiej i „procesu nowoczesności”; 4. różne formy oddziaływania „kobiecej” eschatologii (skrytej w zbiorowej nieświadomości, w „krypcie” kultury patriarchalnej); 5. możliwość pojawienia się konfliktu kultur i kryjących się w nim zagrożeń; 6. nieuchronne stereotypy, strukturalizujące ludzkie doświadczenie świata przez kreowanie kolejnych mentalnych dualizmów (a następnie usuwanie ich w cień - bez Heglowskiej syntezy); 7. wypracowane w kulturze polskiej techniki obcowania z Rosją i rosyjskością; 8. prawdziwe (nie zaś ukształtowane sztucznie, przez pełne uprzedzeń stereotypy) osobliwości kultury rosyjskiej, czyli naprawdę odmienne rozstrzygnięcia w sferze semiotyki tejże kultury, powodujące, że Rosja „nie jest Zachodem” (czy też nie w pełni nim jest).

Zagadnień tych dotyka w swej monografii Anna Sobieska w sposób niezwykle subtelny, nie pretendując bynajmniej do ich rozstrzygnięcia, a nawet przedwczesnej konceptualizacji. Materiałem, na którym bazuje refleksyjna warstwa tej książki, jest bowiem przede wszystkim wnikliwie interpretowana poezja Błoka, drobiazgowa analiza kolejnych polskich przekładów twórczości genialnego Rosjanina, ich aksjosemiotycznych cech, preferencji tłumaczy, kolejnych „zjawień” Błoka w polskim życiu literackim, interpretowanych zawsze w precyzyjnie odtworzonym kontekście historycznym, obyczajowym, socjologicznym. Przy tej okazji - niejako pod pretekstem prezentacji polskich spotkań z Błokiem - monografia Sobieskiej jest też ważnym przyczynkiem do rekonstrukcji życia literackiego i kulturalnego, a nawet codziennego II Rzeczypospolitej. Tym ważniejszym, że dotyka nierzadko spraw słabo zbadanych - np. roli porewolucyjnej emigracji rosyjskiej w warszawskim 
życiu literackim dwudziestolecia lub kwestii wstydliwie przez oficjalną kulturę przemilczanych, jak choćby popularność rosyjskich cygańskich romansów w międzywojennej Warszawie.

Spośród zasugerowanych przez autorkę rozstrzygnięć wymienionych wyżej „wokół-Błokowskich” zagadnień, które wydają się ważne i twórcze, istotny jest problem odmiennego pojmowania i wartościowania wolności w obu kulturach. O ile ukształtowany na ziemiach polskich stereotyp głosił, że kultura rosyjska właściwie tego pojęcia nie zna, a w każdym razie obce jest jej zachodnie rozumienie wolności, skorelowane z odpowiedzialnością za własne czyny, to z analizy wpływu Błokowskich motywów na poetów polskich, przede wszystkim skamandrytów, a także z fascynacji cygańskim romansem w kręgach polskiej elity oraz z popularności tematów cygańskich wśród polskich poetów wynika coś zupełnie innego. Anna Sobieska podkreśla wyjątkowość kultury rosyjskiej w relacji wobec kultury Romów - mianowicie pełną akceptację, włączenie jej elementów do własnej kultury niejako na równych prawach (jak pisze autorka monografii: „Rosjanie okazują się jednym z nielicznych narodów, który kulturą Cyganów zachwycił się do tego stopnia, że pozwolił jej stać się częścią kultury własnej, a cygańskie śpiewanie włączył niejako w struktury własnej wizji świata i człowieka"- s. 235). Tymczasem przeczucie i doświadczenie wolności zawarte w tej wizji okazuje się znacznie radykalniejsze, a tym samym bywa prawdziwsze niż okcydentalne pojmowanie wolności jako „wzniosłej idei”. Jest to wolność, która omija niejako sferę polityczną ludzkiego bytu, zawiesza ją w irrelewancji, odwołując się w zamian do czegoś znacznie bardziej archaicznego - cygańskiej „nomadyczności” jako stylu życia, tęsknoty do wyzwolenia się z okowów miejsca i czasu. Nie bez racji zatem Sobieska stwierdza: „To właśnie święty czas początków, w jaki wkroczyli Cyganie, sprawit, że stali się oni częścią mitu przekształcającego się w epos, a więc próbą odpowiedzi na pytania o najbardziej męczące ludzkość tajemnice i sens ziemskiej codzienności” (s. 293). Autorka monografii przekonująco udowadnia, że Cyganie - w Rosji włączeni w system kulturowy poprzez swoją muzyczną twórczość - stanowią dla kultury Zachodu wyzwanie wręcz filozoficzne.

Wśród licznych zagadnień przywołanych w książce Wokót Aleksandra Btoka warto również zwrócić uwagę na cenne wejrzenia badaczki w samą naturę agresywnie napierającej nowoczesności, wyrażającej się w Rosji w idei rewolucji, a także w logice rewolucyjnych wydarzeń i towarzyszącym im (lub przeciwnie - będącym ich przyczyną i katalizatorem) nastroju, znakomicie oddanym przez Błoka m.in. w poemacie Dwunastu. Autorka przekonująco udowadnia - posługując się skrupulatnymi analizami semantycznymi - że polskie przekłady poematu zmierzają do „ujednoznacznienia” jego sensów, skojarzenia ich z tym, co destrukcyjne. (Nawiasem mówiąc - właśnie „ujednoznacznienie”, będące sygnałem „politycznej” intencji prze- 
kładu, w tym wypadku gestu odseparowania się od Innego, było jedną z najczęściej stosowanych strategii przyswajania rewolucyjnej Rosji kulturze polskiej poprzez sytuowanie jej w miejscu z góry określonym i dla niej przeznaczonym, czyli w roli „oskarżonego” lub „potępionego”. Drugą taką techniką była oczywiście doskonale dziś znana orientalizacja). Prawda na temat rewolucji była jednak - jak udowadnia Sobieska posługując się „medium” poezji Błoka i jej polskiej recepcji - znacznie bardziej wieloznaczna (a zarazem, zapewne, bardziej tragiczna). Skojarzenie rewolucji z motywem chłystowskiego tańca mistycznego, radienija, czy też z praktykami innej słynnej sekty staroobrzędowców - samosżigatieli (którzy - w proteście przeciwko reformie Cerkwi, uknutej ich zdaniem przez Szatana - dokonywali masowych samospaleń) pozwala ujrzeć w niej fenomen aktywnej reminiscencji tego, co archaiczne, płynące z głębin zbiorowego Nieświadomego i co stanowi być może także ukryte źródła dynamiki samej nowoczesności. Chodzi o odsłonięcie (w społecznej semiosferze) - (para)religijnego podłoża kultury i cywilizacji, które ujawnia się w tych zjawiskach (nowoczesności i rewolucji) w postaci nieuformowanej, wolnej od wszelkich dogmatów i rytuałów, od wpływu logosu. Jest to oczywiście „demoniczność” - nie tylko samej rewolucji, ukazana, jak przekonuje autorka studium, w poezji Błoka, ale i doświadczana przez poetę w sposób bezpośredni, jako demoniczność własna.

Jako zachodni kontekst tej interpretacji przywołać można oczywiście Nietzschego (wraz z „demonem - karłem” towarzyszącym Zaratustrze), a także Kierkegaarda (zwłaszcza studium Pojęcie lęku, gdzie definiuje on demoniczność jako „coś, co jest szybkie - ze względu na ruch i krótkie - ze względu na czas”), a wcześniej - europejski i rosyjski romantyzm. Owa demoniczność ujawniona w semiosferze daje się opanować przez taniec (motyw tańca u Nietzschego, a także pojawiająca się w rosyjskim symbolizmie interpretacja rewolucji jako stanu chłystowskiego „opętania”), muzykę lub rytm. Jak pisze Sobieska: „Uwydatniona przez Błoka przemiana, jaka dokonuje się dzięki muzyczności, będącej esencją rewolucyjnej siły, muzyczny rytm kroków piechoty, śpiewające, dźwięczne zamiecie, odgłosy tańca mazura - oznacza ujawnienie się muzyki bytu, muzyki związanej z ujawnieniem się bytowej żywiołowości. Rewolucja więc w swoim najbardziej mistycznym znaczeniu była dla niego wyrazem ducha muzyki, istoty samego bytu [...]" (s.352). Idąc dalej, można byłoby zadać pytanie: czy starcie dwóch totalitaryzmów w wieku XX nie było zderzeniem dwóch „ateistycznych” formacji religijnych (czy też, wyrażając się ostrożniej, za autorką - „struktur mentalnych «napikowanych» tradycjami religijnymi” - s. 227), z których jedna reprezentowała bogatą w symbole, lecz pogrążoną w upadku „duszę Rosji”, gdzie „Logos nie włada Kosmosem” (jak mówi autorka za Bierdiajewem s. I63), druga zaś - anty-symboliczny (skoncentrowany na performatywnej funkcji 
języka, na Heideggerowskiej „poetyce rozkazu”), immanentystyczny Nietzscheański „mit woli”? Niezależnie od sensowności postawionego tu pytania należy stwierdzić, że nowoczesność, wraz z wymuszaną przez nią dynamiką społecznych znaczeń, powinna stanowić nieodzowny kontekst rozważań o semiotycznej dialektyce literatury początku XX wieku (i tak jest istotnie w omawianej monografii).

Stworzona przez Annę Sobieską wieloraka i różnorodna układanka barwnych kulturowych fragmentów, rekonstrukcji, wglądów i interpretacji (nawiązując do sformułowania z zakończenia książki) prowokuje do uogólnień, formułowania hipotez, zmusza do myślenia. Jest to cecha twórczości naukowej wysokiego lotu. W obrębie zaś perspektywy, która została zarysowana we wstępie studium Wokót Aleksandra Btoka - czyli zmagań z polską rusofobią - stanowi ona naprawdę duży krok do przodu. Zarówno dobór tematyki tej książki, jak i sposób jej ujęcia świadczą ponadto o wyjątkowo dobrym wyczuciu autorki w zakresie dobierania właściwych i ważnych tematów, o niezwykle trafnym rozpoznaniu przez nią potrzeb wspó1czesnej humanistyki i polskiej kultury. 